\title{
Problems of CIT application in distant foreign language and professional communication teaching
}

\author{
Tatiana Koshel $^{1 *}$ \\ ${ }^{1}$ Don State Technical University, Gagarin sq., 1, Rostov-on-Don, 344003, Russia
}

\begin{abstract}
The article examines higher education at the stage of transformational processes of transition to the global educational space. The importance of the discipline of a foreign language, as a means of intercultural, scientific and academic interaction in a given space is emphasized. The issues of the introduction of information and communication technologies in the process of teaching a foreign language are considered. The main regulatory documents in this area are considered. The definition of information and communication technologies as applied to the process of teaching a foreign language is given. Educational online platforms for teaching professional communication in a foreign language have been analyzed. The importance of interaction between the university and secondary school in the formation of a consistent trajectory of teaching a foreign language and professional communication in a foreign language is emphasized. Problems on the way of digitalization of the educational process are identified and solutions are proposed.
\end{abstract}

\section{Introduction}

Modern world is undergoing global changes. Life itself and its various social and other institutions are being transformed. Moreover, all these global changes cannot but have an impact on the development of education. In Europe, back in the 70s of the last century, the institute of education embarked on the path of integration and globalization. Russia joined the Bologna Declaration only in 2003. Since then, a thorny path to the global educational environment began. Someone perceives this process with enthusiasm - this is mainly the younger generation, which is not yet accustomed to the established traditional Russian education. For many older people all these changes cause rejection. However, there is no turning back and we must overcome this transition period. What does joining a single European educational environment give us? The general educational space is the mobility of citizens with employment opportunities, high-quality competitive education, strengthening of the intellectual, cultural, social, scientific and technical potential of European countries. If we are talking about globalization, we need to focus on the means of global intercultural communication, namely language.

*Corresponding author: tatakosh@mail.ru 
The main language of a unified educational environment is English, which itself began to transform in the light of such rapid changes. In addition, when we talk about English as a means of communication in a non-linguistic environment, we are often talking about a new synthetic form of the English language - Globish (global English), which is a simplified version of the English language with a sufficient set of means for communication in a nonnative environment. If we are talking about linguists or students who want to take separate modules of disciplines in English-speaking countries, they, of course, need to study Standard English.

In this digital age, it is possible to get an education from the comfort of your home. However, you need to master these technologies. Information and communication technologies provide incredible scope for learning a foreign language, communicating with native speakers, intercultural and professional communication. Every foreign language teacher is simply obliged to plunge into this amazing world of digital technologies and to captivate their students. However, this often causes many problems, which we will focus on in this article.

It is no secret that many schools continue to study a foreign language according to the old conservative methods, working only with a textbook. Applicants come to universities completely unprepared for intercultural communication. Many have developed a psychological barrier that prevents them from speaking a foreign language; some students have lost all interest in learning the language, citing a lack of ability. What happens in modern schools, if in groups of non-linguistic specialties there are a maximum of three or five well speaking students, the rest left the school with zero knowledge of a foreign language. Now we do not live behind the Iron Curtain, are not cut off from the whole world, we are slowly entering a single educational environment. Therefore, the issue of teaching a foreign language and in the future professional communication in a foreign language is topical and relevant as never before.

In the light of recent events in the world, the use of information and communication technologies (ICT) in the educational process is becoming more widespread. Russian education is going through a turning point in the formation of total digitalization, i.e., the introduction of electronic document management tools (both internal and external), corporate mail, student assessment through a remote system, and the use of online learning.

The Russian Federation has an innovative scenario of socio-economic development aimed at improving the quality of its citizens' life and ensuring Russia's competitiveness, that is why the Ministry of Digital Development, Communications and Mass Media of the Russian Federation has developed a state program "Information Society" [1]. One of the planned results of this program is to ensure the development of services based on ICT, including in the spheres of culture, education, science and health.

In our country, federal interdepartmental and sectorial programs are being implemented aimed at solving urgent problems of informatization of education, including the development of the infrastructure of a unified educational information space, the development of electronic educational resources, advanced training of teachers in the use of ICT, their implementation in the organization of the educational process, the practice of educational management. [2]

In this regard, there is an increasing need for research on the technologies used in the education process, including teaching a foreign language and, in particular, professional communication in a foreign language. This, in turn, determines the goal of our study - to consider ICTs used in the educational process in teaching a foreign language and the specifics of teaching a foreign language in particular, professional communication at a university in a distance form. 


\section{Materials and methods}

Issues of the education system in Russia are considered in various fields of scientific research, sociological, pedagogical, methodological, and philosophical.

Of particular interest to educational researchers are the trends in the modernization of the higher education system. The main directions of modernization of higher education, its goals and objectives are considered in the works of T.M. Dadaeva [3], Kovrizhnykh OA, and Gavrilova Yu.V. [4].

Modernization issues related to the informatization of higher education also attract the attention of modern researchers. The analysis of the process of informatization of the education system, as well as consideration of the consequences of this process, are presented in the work of A.G. Asmolov, A.L. Semenov, and A.Yu. Uvarov, who believe that such a process entails the emergence of a situation where teachers can no longer teach in the old way, while experiencing a lag behind students in the field of mastering information technology [5]. These circumstances indicate that the process of informatization of the educational environment is much broader than the banal technical modernization or computerization of educational institutions, which causes a large number of questions from researchers.

Some studies in this area are devoted to the methodological and technological aspects of distance learning [6]. In some works, aspects of the use of distance learning technologies for training students at a university are also touched upon, where it is noted that innovative teaching aids increase interest in the study of the discipline and the educational process in general $[7,8]$.

Undoubtedly, the introduction of distance learning technologies within the framework of the implementation of educational programs is of interest to scientists from the point of view of scientific and methodological principles and socio-psychological [9, 10,] and pedagogical aspects of diagnostics and the effectiveness of using the distance learning system [11].

Methods of overcoming the pedagogical and technical difficulties encountered by teachers of a foreign language who begin to work in an online format are considered in the works of a leading teacher, linguist and methodologist Ignatenko I.I. [12] who methodically relies on the experience of foreign methodologists Moore M. G., Anderson W. G. [13].

Various aspects of ICT and their role in teaching and upbringing are touched upon in the works of G.A. Berulava, E.S. Polat, L.K. Raitskaya, P.V. Sysoeva, V.A. Testova, V.A. Travneva and others [14].

The experience of recent months, forcing the faculty and students to immerse themselves in the active use of information and communication technologies in the educational process, makes it possible to consider the mode of distance learning of a foreign language from the point of view of trial and error analysis [15].

The theoretical and methodological basis of this study is built based on the institutional approach (E. Durkheim, M. Weber), which allows us to judge the goals and objectives of vocational education. Within the framework of this approach, we evaluate the existing rules and norms governing the relationship between the actors of the educational process, which allows us to evaluate pedagogical decisions in the course of the educational process. It is also important to take into account the structural-functional approach (E. Durkheim and T. Parsons), which makes it possible to analyze education as a stable social system with a set of invariable qualities. In connection with the ongoing transformation processes and the modernization of the education system, it is advisable to apply a multi-paradigm approach to the study of the education system proposed by Epikhina Y.B. [16]. This approach will allow the most comprehensive study of new trends in the education system, among which the development and active implementation of innovative educational technologies, 
including distance learning, prevails. In addition, an important role within the framework of this study is played by such concepts as the creation of educational programs and the concept of individualization and differentiation of education, which make it possible to record the consequences of the distance-learning regime in higher education.

\section{Results and discussion}

To begin with, let us give the definition of information and communication technologies. Information and communication technologies (ICT) are processes, methods of searching, collecting, storing, processing, providing, disseminating information and ways of implementing such processes and methods (Federal Law No. 149-FZ) [17]. The Internet offers its users a variety of information and resources: e-mail; teleconferences and videoconferences; the ability to publish your own information, create your own home page; access to information resources; reference directories and search engines; conversation on the net. Various training resources, dictionaries, reference books, catalogs are freely available.

In order to integrate information resources of various educational platforms, universities, libraries, the information system "Single Window of Access to Educational Resources" (http://window.edu.ru) was created for general and professional education.

All ICTs used in the learning process can be structured according to their purpose, as presented in Table 1.

Table 1. Information technologies used in the learning process

\begin{tabular}{|l|l|}
\hline ICT & Purpose \\
\hline Demonstration materials & $\begin{array}{l}\text { Illustrations, drawings, photographs, posters, } \\
\text { presentations, diagrams with text accompaniment or } \\
\text { just text, animations or videos. }\end{array}$ \\
\hline Interactive materials & $\begin{array}{l}\text { Interactive tables, rules and educational texts for the } \\
\text { analysis of language and speech material, at the stage } \\
\text { of explanation, consolidation and repetition of new } \\
\text { material. }\end{array}$ \\
\hline Educational dictionaries & $\begin{array}{l}\text { Explanatory and bilingual dictionaries of foreign } \\
\text { languages posted on the Internet. }\end{array}$ \\
\hline Electronic assignments & $\begin{array}{l}\text { Practice tests and tasks with feedback function, all } \\
\text { kinds of language games. }\end{array}$ \\
\hline
\end{tabular}

In the process of classroom work, multimedia equipment (computer, video projector, screen or TV) can be actively used; as well as interactive whiteboards that give the learning process a playful form, making it possible to combine various activities with the use of various receptors for the perception and assimilation of information. Work in a computer class can be actively used for project work in a team, where the roles of searching and processing information for project presentation are clearly assigned. The Internet provides tremendous opportunities to diversify the lesson, supplement it with interactive tasks, and is indispensable in the process of distance learning.

The problems of introducing ICT into the learning process became especially acute during the pandemic. Self-isolation has become a "litmus test" for determining readiness for distance learning. Since the generation - $\mathrm{Z}$ born in the information environment has come to schools and universities, their digital skills often exceed the level of their teacher's skills in working with electronic media. An important task facing modern teachers is to improve their digital literacy, to select the resources corresponding to the course program and aimed at the formation of language competencies according to the demands of the program. 
In our opinion, when working on an electronic course in the discipline of a foreign language, teachers were in a more advantageous position in comparison with teachers of other disciplines. After all, the Internet offers a wide range of free educational platforms such as Deutsche Welle https://www.dw.com/de/deutsch-lernen/deutsch-unterrichten/s2233 (German); British Council website https://www.britishcouncil.org/english/kids-teens (English); Alliance Francais https://www.institutfrancais.ru/ru/regions/alyans-fransez (French) and others offering a huge selection of audio and video content, online tests, etc.

The main task of the teacher is to select and structure the necessary material in accordance with the course program and choose a convenient platform:

- Skype is a more suitable platform for individual and pair lessons.

- Zoom is a platform for group lessons.

With the help of Screencast-o-manic, Bandicam or Zoom programs, you can record detailed video instructions for trainees with voice explanations. Before starting, you can make a test call to the trainee on the platform chosen for the lessons.

After analyzing the content of the "E-Net School" platform, as well as the reports of teachers on various Internet sites on the use of ICT in teaching a foreign language, the following problems can be identified:

- Insufficient material and technical base;

- Lack of educational content (audio, video lessons, electronic supplements to textbooks, as well as teaching aids in electronic form);

- Insufficient level of ICT proficiency among teachers,

- Lack of uniform Russian platforms with training and methodological content for teaching a foreign language and language of professional communication.

A period of self-isolation prompted educators to try out various platforms for online learning. Some educational institutions generally went on long-term vacations, explaining such actions by insufficient technical equipment and the lack of the necessary digital literacy of teachers.

In the strategy of organizing distance education, it is proposed to use the educational content of television programs, recordings of lessons posted on YouTube, on the websites of various specialized platforms.

To solve the problems of professional communication in a foreign language, we consider it expedient to introduce into the learning process the resources of educational platforms that provide professional courses mainly in English. Some platforms also offer learning other foreign languages. Let us take a look at the most popular educational platforms for teaching professional communication in English.

Here is the overview of some platforms. All of them are united by one name - Massive Open Online Course (MOOC), i.e. a training course with massive interactive participation using e-learning technologies and open access via the Internet, as a form of distance education. As a complement to traditional curriculum materials such as videos, reading and homework, MOOC provide the opportunity to use interactive user forums to help build and maintain communities of students and teachers. Video recordings of lectures from various educational institutions began to appear on the Internet in the late 1990s, but only MOOC, which appeared for the first time in the early 2010s, made it possible for students and teachers to communicate interactively, as well as take exams online. MOOC gained widespread popularity only in 2012, when projects such as Coursera, Udacity and Udemy raised their first investments. Early MOOC sites (like Udacity) often promoted the concept of open access (open content). Later sites made access to content paid, leaving the possibility of full or partial free training. Such sites are created for listeners of various levels of training - both for beginners and experienced specialists. The most popular massive online courses attract hundreds of thousands of students. Regional MOOCs teach in national languages and are focused on solving the problems of a particular country or 
region. Often these resources are financed by government agencies. These include the above-mentioned Russian platform "Single Window of Access to Educational Resources" [18].

Let us take a closer look at the top ten online courses, perhaps some of them can become part of an interactive course in a specialized discipline in teaching professional communication. In this case, we are dealing with the mastering and development of both the skills of using ICT and the skills of professional communication. We presented the top ten MOOC in Table 2.

Table 2. Ten most known Massive Open Online Courses

\begin{tabular}{|c|c|c|c|}
\hline No & MOOC & Description & Course topics \\
\hline 1. & Coursera & $\begin{array}{l}\text { The largest educational } \\
\text { resource offering free content } \\
\text { on various professional topics }\end{array}$ & $\begin{array}{l}\text { Business, social sciences, } \\
\text { physics, computer science, } \\
\text { personal development, data } \\
\text { science, life sciences, } \\
\text { mathematics and logic, } \\
\text { language learning, } \\
\text { humanities and arts. }\end{array}$ \\
\hline 2. & Edx & $\begin{array}{l}\text { The project of University of } \\
\text { Massachusetts that offers many } \\
\text { professional courses, including } \\
\text { free ones. Most professional } \\
\text { courses are paid, and the } \\
\text { requirements for students are } \\
\text { high: the certificate is issued } \\
\text { only to those who completed } \\
\text { their homework on time and } \\
\text { successfully. It is because of } \\
\text { this Edx is considered the best } \\
\text { platform for deep expertise }\end{array}$ & $\begin{array}{l}\text { Architecture, art and culture, } \\
\text { biology, business and } \\
\text { management, economics and } \\
\text { finance, data analysis and } \\
\text { statistics, chemistry, } \\
\text { computer science, design, } \\
\text { teacher education and } \\
\text { training, electronics, } \\
\text { environment, food and } \\
\text { nutrition, health and safety, } \\
\text { history, language studies, } \\
\text { jurisprudence, literature, } \\
\text { mathematics, medicine, } \\
\text { music, philosophy and } \\
\text { ethics, physics, etc. }\end{array}$ \\
\hline 3. & Udemy & $\begin{array}{l}\text { One of the simplest and most } \\
\text { user-friendly educational } \\
\text { projects out there. The } \\
\text { peculiarity of Udemy is that } \\
\text { free courses usually do not } \\
\text { require doing homework and } \\
\text { consist of short, capacious } \\
\text { videos - you spend a minimum } \\
\text { of time getting the necessary } \\
\text { knowledge and determine the } \\
\text { pace of learning yourself. } \\
\text { Another feature of this site is } \\
\text { that you can create your own } \\
\text { course on the platform and } \\
\text { make money from it. }\end{array}$ & $\begin{array}{l}\text { Web development, IT and } \\
\text { software, business, } \\
\text { marketing, education, } \\
\text { photography, health and } \\
\text { fitness, language learning, } \\
\text { personal development, } \\
\text { music, design, teacher } \\
\text { training, test preparation, etc. }\end{array}$ \\
\hline 4. & Khanacademy & $\begin{array}{l}\text { A non-profit organization that } \\
\text { grows primarily through } \\
\text { donations from Google, the Bill } \\
\& \text { Melinda Gates Foundation, } \\
\text { and user donations. The main } \\
\text { advantage of the resource is an } \\
\text { easy presentation of any topic, } \\
\text { while some materials are taught }\end{array}$ & $\begin{array}{l}\text { Mathematics, economics and } \\
\text { finance, computer science, } \\
\text { art, cosmology and } \\
\text { astronomy, health and } \\
\text { medicine, history, music, etc. }\end{array}$ \\
\hline
\end{tabular}




\begin{tabular}{|c|c|c|c|}
\hline & & in a playful way. & \\
\hline 5. & Openlearning & $\begin{array}{l}\text { An Australian distance-learning } \\
\text { project founded by experts } \\
\text { from the University of New } \\
\text { South Wales. The main } \\
\text { difference of this site is that it } \\
\text { positions itself not only as an } \\
\text { educational platform, but also } \\
\text { as a social network for those } \\
\text { wishing to gain knowledge. } \\
\text { The materials consist of } \\
\text { detailed video lectures as well } \\
\text { as discussion questions to } \\
\text { which you will need to give a } \\
\text { written answer in English. You } \\
\text { will be able to participate in } \\
\text { discussions with native } \\
\text { speakers, exchange knowledge } \\
\text { and practice writing messages } \\
\text { in English. }\end{array}$ & $\begin{array}{l}\text { Art and design, education, } \\
\text { business and economics, } \\
\text { computer science and } \\
\text { technology, health and } \\
\text { medicine, law, lifestyle, self- } \\
\text { development, sports and } \\
\text { fitness, language learning, } \\
\text { mathematics, etc. }\end{array}$ \\
\hline 6. & Alison & $\begin{array}{l}\text { Irish educational resource that } \\
\text { collaborates with such giants as } \\
\text { Google, Microsoft, Macmillan, } \\
\text { etc. The main difference of the } \\
\text { project is that it provides } \\
\text { completely free training. }\end{array}$ & $\begin{array}{c}\text { Banking, business, } \\
\text { management, tourism, } \\
\text { biology, anatomy, chemistry, } \\
\text { music, mathematics, } \\
\text { language studies, sociology, } \\
\text { psychology, photography, } \\
\text { yoga, law, physics, web } \\
\text { development, etc. }\end{array}$ \\
\hline 7. & Stanford Online & $\begin{array}{l}\text { Distance learning from one of } \\
\text { the world's most prestigious } \\
\text { educational institutions. }\end{array}$ & $\begin{array}{l}\text { Economics, statistics, social } \\
\text { sciences, engineering, } \\
\text { medicine, education, } \\
\text { language learning, etc. }\end{array}$ \\
\hline 8. & Canvas Network & $\begin{array}{l}\text { A popular learning resource } \\
\text { abroad. Almost every course } \\
\text { has homework that you must } \\
\text { complete; otherwise, you will } \\
\text { not be able to attend the course. }\end{array}$ & $\begin{array}{l}\text { Medicine, economics, sports } \\
\text { and health, mathematics, } \\
\text { computer science, etc. }\end{array}$ \\
\hline 9. & FutureLearn & $\begin{array}{l}\text { A British MOOC project that } \\
\text { collaborates with the British } \\
\text { Council, Birmingham, Bristol, } \\
\text { Liverpool Universities, the } \\
\text { British Museum, etc. and has } \\
\text { been developing distance and } \\
\text { online education for over } 40 \\
\text { years. }\end{array}$ & $\begin{array}{l}\text { Business and management, } \\
\text { creative arts and media, } \\
\text { healthcare and psychology, } \\
\text { history, languages and } \\
\text { cultures, law, literature, } \\
\text { nature and environment, } \\
\text { online technology and } \\
\text { electronics, politics and the } \\
\text { modern world, science, } \\
\text { mathematics and technology, } \\
\text { sports and healthy lifestyles, } \\
\text { pedagogy and teaching }\end{array}$ \\
\hline
\end{tabular}




\begin{tabular}{|c|c|c|c|}
\hline 10. & $\begin{array}{c}\text { Courses from the teachers of } \\
\text { the famous Yale University. } \\
\text { You can attend lectures by } \\
\text { eminent professors without } \\
\text { leaving your home. Any } \\
\text { material you are interested in } \\
\text { can be downloaded free in the } \\
\text { form of a video, audio } \\
\text { recording or text; there are no } \\
\text { verification tests and } \\
\text { homework here. This is a great } \\
\text { resource for people who want } \\
\text { to broaden their horizons and } \\
\text { do not aim to be certified. }\end{array}$ & $\begin{array}{c}\text { Language studies, literature, } \\
\text { economics, history, } \\
\text { psychology, sociology, } \\
\text { philosophy, physics, etc. }\end{array}$ \\
\hline
\end{tabular}

Russian universities have also started publishing their online courses on MOOC platforms. The pandemic has forced universities to mobilize and create electronic products not only for internal use, but also for open educational platforms. For some universities it is a new experience. Some create electronic courses only for their own students.

Course Burg company has conducted a study "Online Education 2020: Which Russian Universities Are Ready for Distance Learning". They analyzed 710 online courses published by 19 Russian universities. The data were taken from the official report of the Ministry of Science and Higher Education of the Russian Federation, based on published courses from the website Modern Digital Educational Environment (DECE).

Number of online courses published by Russian universities in 2020

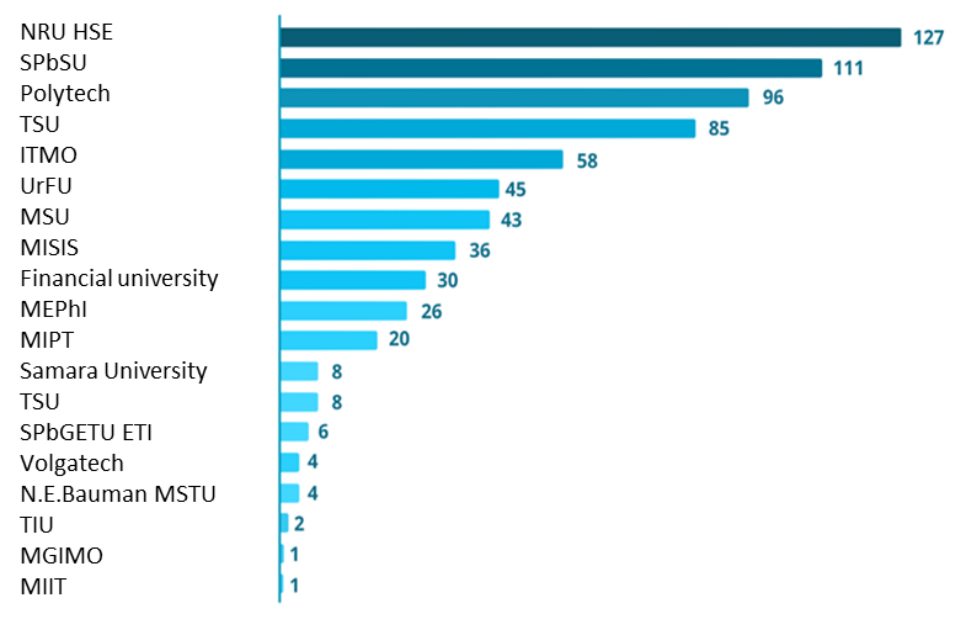

Fig. 1. Number of online courses published by Russian universities in 2020 :

NRU HSE became the absolute leader in publishing its online courses, publishing $18 \%$ of all online courses, while SPbU took second place with $16 \%$. The third, fourth and fifth positions were taken by Polytech (14\%), TSU (12\%) and ITMO University (8\%), respectively.

A total of eleven MOOC platforms have been used by universities to publish their online courses. The most popular platform for publishing courses was the National Open Education Platform (NPET), with $68 \%$ of all courses published on it. In addition, the most popular platforms for posting materials were Coursera - $20 \%$ of courses, Open Online 
Academy - 4\% of courses, SPbPU SDO (Moodle) - 2\% of courses and Edx - 1\% of courses [19].

Thus, these days, anyone seeking to obtain high-quality professional knowledge, or improve his or her language skills can use educational online platforms. A wide range of training videos on various professional topics is openly available on the YouTube. However, not everyone can organize his or her own education.

The main task of a foreign language teacher in teaching professional communication in a foreign language is to select relevant material corresponding to a specialist-training program and help develop self-education skills in an online format, which in our changing digital age is so necessary for continuous education, improving professional and intercultural skills of communication in the global space of today and tomorrow.

The modern world is changing rapidly. The transformation of the academic environment is taking place. Today, students and faculty have the opportunity to become part of the global academic environment, receive education or take courses in selected disciplines at various universities. The university can invite teachers of native speakers. English is becoming a universal means of interaction in the global educational space. The main task of foreign language teachers is to keep up with the times, master new teaching methods, integrate the existing experience of world universities and, of course, improve their own knowledge.

When creating methodological and educational content for electronic courses on teaching a foreign language at a university, it is necessary, in our opinion, to refer to the experience of the aforementioned international educational platforms for learning foreign languages and to provide subsequent professional support (methodological and technical) for their continuous functioning and development.

To make wider use of the possibilities of network educational programs in the integration of basic and additional education, to expand the Olympiad movement, work on project and research activities.

\section{Conclusion}

In 2003, Russia joined the Bologna Declaration, which implied global changes in the academic environment of Russian universities:

Implementation of education quality control systems within higher education institutions and involvement of all stakeholders in the external independent assessment of the activities of higher education institutions: representatives of the academic community, the state, students and employers.

Adoption of a system of comparable degrees, to ensure the employability of European citizens and to increase the international competitiveness of the European higher education system.

Introduction of two-level study: Bachelor and Master's.

Implementation of the European credit system to maintain student mobility, as well as to ensure the student's right to choose the disciplines studied. It was based on ECTS (European Credit Transfer System) - a cumulative assessment system to achieve the goals of the concept of "lifelong learning".

Development of the mobility of students, teaching staff and other categories of educational workers by offsetting the period of time they spend working in the European region. Development and implementation of standards for transnational education.

Maintaining and developing the traditional European approach to the implementation of higher education, especially in the areas of curriculum development, inter-institutional cooperation, mobility schemes and joint study programs, practical training and research $[20,21]$. 
The transformation process of Russian universities is not going entirely smoothly. It is difficult for the faculty to restructure the format of the usual work. However, everyone understands that changes are inevitable, since the world itself has transformed and become different, requiring flexibility and breadth of thinking from the teacher.

Within the global space, foreign languages, and primarily English, are becoming a means of interaction both in science and in intercultural communication. Therefore, the teacher of foreign languages has an important task to improve his professional skills. Mastering and introducing ICT into the educational process, which will make it possible to successfully solve many pedagogical tasks [22] themselves, such as:

Implementation of the principle of individualization of the educational process,

Improving the efficiency of the educational process,

Enhancing the cognitive activity of students,

Implementation of the principle of interactivity [23].

Formation of lifelong learning skills.

In our opinion, the transformation of higher education should begin from its foundation, namely the secondary general education school. Learning should be a complex systematic process. To do this, universities must supervise schools; find ways of interaction, such as subject Olympiads, competitions, joint events, sponsorship, open lessons, lectures, professional development of teachers, training in digital literacy etc. Only in close cooperation and a clear vision of the result, we will be able to get worthy applicants, and in the future, university graduates.

\section{References}

1. State Program of the Russian Federation "Information Society (2011-2020 [Electronic resource] URL: https://rossvyaz.gov.ru/deyatelnost/gosudarstvennyeprogrammy/gosudarstvennaya-programma-rossiiskoi-federacii-informacionnoeobshestvo-2011-2020- gody (accessed: 25 Dec. 2020)

2. M. V. Trubitsyna. Modern digital educational Internet resources in the study of a foreign language Creative project. URL: https://infourok.ru/sovremennie-cifrovieuchebnie-internet-resursi-v-izuchenii-inostrannogo-yazika-399847.html)

3. T.M. Dadaeva. Higher education reform: paradoxes and dead ends of institutional changes. University management: practice and analysis. (2014). No. 4-5 (92-93). Pp. $28-35$.

4. O.A. Kovrizhnykh, Yu.V. Gavrilova, Society: sociology, psychology, pedagogy 2 (70), 103-108 (2020)

5. A.G. Asmolov, A.L. Semyonov, A.Yu. Uvarov. Russian school and new information technologies: a look into the next decade (Publishing house NexPrint Moscow, 2010)

6. Higher education in the world: what problems highlighted by the pandemic. URL: https://tass.ru/opinions/8306213

7. D.A. Petrov, Integration of modern information technologies as a method of improving the educational process in higher educational institutions. Moscow University for the Humanities, 2 (2020)

8. T.B. Mikheeva, E.V. Murugova, Y.S. Morozova, V.I. Demchenko. Training as a major tool of teacher professionalism enhancement. INTED (2020) Proceedings 14th International Technology, Education and Development Conference 1211-1215 (2020) doi: 10.21125/inted.2020.0417

9. T. Koshel, N. Manuylova, N. Revyakina, E. Sakharova. SHS Web of Conferences 70, 08021 (2019) doi: https://doi.org/10.1051/shsconf/20197008021 
10. T.B Mikheeva, E.V. Murugova. SHS Web Conf. 70, 07003 (2018) doi: https://doi.org/10.1051/shsconf/20197007003

11. A.A. Akhayan. Theory and practice of the formation of distance pedagogical education (SPb. 2001)

12. I. I. Ignatenko. Teaching Aspects of a Foreign Language Online Problems of modern education 3, (2019)

13. M. G. Moore, W. G. Anderson (eds.) Handbook of distance education (London: Lawrence Erlbaum Associates, 2003)

14. O.A. Chekun, I.I. Lushnikova. Modern technologies in teaching foreign languages to the digital generation of students. URL: https://cyberleninka.ru/article/n/sovremennyetehnologii-v-obuchenii-inostrannym-yazykam-tsifrovogo-pokoleniya-studentov/viewer

15. S.V. Pervukhina, G.I. Radchenko. E3S Web of Conferences 210, 18036, 1-10 (2020) https://doi.org/10.1051/e3sconf/202021018036

16. Y.B. Epikhina. The influence of economic and cultural resources on the performance of schoolchildren from large families (Moscow, 2011)

17. Federal Law of July 27, 2006 No. 149-FZ on Information, Information Technologies and Information Protection [Electronic resource] URL: http://www.kremlin.ru/acts/bank/24157

18. O. Gorbatenko. Ten educational platforms: where to get knowledge in English. URL: https://englex.ru/educationalplatforms/?utm_source=admitad\&admitad_uid=850f128abd $1 \mathrm{fcfd} 145 \mathrm{e} 935 \mathrm{~b} 0 \mathrm{be} 6 \mathrm{a} 0 \mathrm{e} 26$

19. A. Alkhov FORBES Council URL: https://blogs.forbes.ru/2020/07/03/issledovaniepokazalo-kakie-rossijskie-vuzy-okazalis-luchshe-vsego-gotovy-k-perehodu-nadistancionnoe-obuchenie/

20. D.A. Petrov. Integration of modern information technologies as a method of improving the educational process in higher educational institutions (2020)

21. E.V. Murugova, S.V. Evtushenko, V.I. Demchenko, V.A. Grekova. Learning Europe through studying and discovering opportunities within the framework of ERASMUS+ Programme. Proceedings of the11th International Conference on Education and New Learning Technologies July 1st-3rd, IATED, 9728-9735 (2019)

22. E. Sakharova, N. Revyakina. E3S Web of Conferences 210, 18040 (2020) Innovative Technologies in Science and Education (ITSE-2020), doi: https://doi.org/10.1051/e3sconf/202021018040

23. I.A. Zimnyaya. Key competencies - a new paradigm of the result of education. Higher education today $\mathbf{5}, 34-42(2003)$ 